\title{
Analysis of Out of Court Medical Dispute Resolution According to the Laws and Regulations Applicable in Indonesia
}

Analisis Penyelesaian Sengketa Medik di Luar Pengadilan Menurut Peraturan Perundang-Undangan yang Berlaku di Indonesia

\author{
Ariko Rahmat Putra; Noormartany; Dony Septriana Rosady \\ email: arikorp@gmail.com
}

Faculty of Medicine, Islamic University of Bandung

\begin{abstract}
The medical profession is a noble profession because it upholds human values. In carrying out the medical profession, there is a legal relationship between doctors and patients, both civil, criminal and state administration. In civil terms, if one of the parties defaults, it will cause a medical dispute. Medical dispute resolution is not only done in court but can also be done outside the court.

The purpose of this research is to find out alternative medical dispute resolution outside the court in accordance with the prevailing laws and regulations.

This research is juridical-normative research. This research describes medical dispute resolution in Indonesia based on the prevailing laws and regulations in Indonesia. Then, analyze each medical dispute resolution option contained in statutory regulations.

The doctor-patient relationship in terms of civil law is a therapeutic agreement. If in the agreement one of the parties is in default, such as a doctor who has committed an act that is detrimental to the patient, it can lead to a medical dispute. Civil medical dispute resolution is not only resolved in court but can also be carried out outside the court through several mechanisms, namely consultation, negotiation, mediation, conciliation and expert opinion.
\end{abstract}

Keyword: The Settlement, Medical Dispute, Outside the Court

\begin{abstract}
Abstrak: Profesi dokter merupakan profesi yang mulia karena menjunjung tinggi nilai kemanusiaan. Dalam melaksanakan profesi kedokteran terdapat hubungan hukum antara dokter dan pasien, baik secara perdata, pidana, maupun tata usaha negara. Secara perdata, jika salah satu pihak melakukan wanprestasi maka menimbulkan sengketa medik. Penyelesaian sengketa medik tidak hanya di dalam pengadilan, tetapi juga dapat dilakukan di luar pengadilan.

Tujuan penelitian ini untuk mengetahui alternatif penyelesaian sengketa medik di luar pengadilan yang sesuai dengan peraturan perundang-undangan yang berlaku.

Penelitian ini merupakan penelitian yuridis-normatif. Penelitian ini mendeskripsikan penyelesaian sengketa medik di Indonesia berdasar atas peraturan perundang-undangan yang berlaku di Indonesia. Kemudian, menganalisis setiap pilihan penyelesaian sengketa medik yang terdapat di peraturan perundang-undangan.

Hubungan dokter-pasien ditinjau dari hukum perdata merupakan perjanjian terapeutik. Jika dalam perjanjian salah satu pihak melakukan wanprestasi seperti dokter yang melakukan tindakan yang merugikan pasien maka dapat menimbulkan sengketa medik. Penyelesaian sengketa medik secara perdata tidak hanya diselesaikan dipengadilan saja, tetapi juga dapat dilakukan di luar pengadilan melalui beberapa mekanisme, yaitu konsultasi, negosiasi, mediasi, konsiliasi, dan pendapat ahli.
\end{abstract}

Kata Kunci: Penyelesaian, Sengketa Medik, Luar Pengadilan 


\section{PENDAHULUAN}

Profesi dokter merupakan profesi yang mulia. Sudah selayaknya sebagai profesi yang mulia, dokter dalam menjalankan profesinya harus sepenuh hati. Profesi dokter merupakan bisikan nurani dan panggilan jiwa untuk mengabdikan diri kepada manusia demi mencapai kesehatan yang paripurna berlandaskan moralitas yang tinggi. Bagi pribadi seorang dokter, harus melekat secara mutlak sikap mental yang mendasar bagi profesi yang luhur ini, yaitu ketuhanan, rasa kemanusiaan, kemurnian niat, keluruhan budi, kerendahan hati, kesungguhan kerja, integritas ilmiah, dan sosial. Dibalik profesinya yang mulia, terdapat tanggung jawab besar yang diemban oleh seorang dokter dalam melaksanakan profesinya, baik kepada manusia maupun kepada hukum. Sehingga dalam melaksanakan profesinya, seorang dokter harus sesuai dengan kaidah hukum yang berlaku ${ }^{1}$

Annie Isfadyrie mengutip hubungan hukum antara dokter-pasien menurut Thiroux, membagi ke dalam 3 sudut pandang, yaitu: ${ }^{2}$

1. pandangan paternalisme yang menghendaki seorang dokter berperan sebagai orangtua terhadap pasien sebagai keluarganya. Dalam pandangan ini seorang dokter memiliki kekuasaan penuh terhadap pengobatan pasiennya. Pasien tidak boleh ikut campur dalam proses pengobatannya. Dalam pandangan ini, dalam melakukan tindakan kedokteran, dokter memegang kendali penuh terhadap kondisi pasien.

2. pandangan individualisme, yaitu pandangan yang beranggapan bahwa pasien yang mengetahui yang terbaik bagi dirinya sendiri. Pasien memiliki kekuasaan yang penuh terhadap apa yang akan dilakukan terhadap dirinya ataupun nyawanya sendiri. Dalam pandangan ini, segala tindakan kedokteran yang akan dilakukan, pasien sendirilah yang menentukan apakah akan mengikuti prosedur medis atau menolaknya.

3. pandangan resiprocal dan kolegial yang beranggapan bahwa pasien dan dokter harus bekerjasama demi memberikan pengobatan yang terbaik kepada pasien. Dokter tidak memiliki kewenangan penuh ataupun pasien juga tidak memiliki kewenangan penuh terhadap dirinya dan dibutuhkan kerjasama antara kedua belah pihak. Dalam pandangan ini peran kedua belah pihak berperan sama pentingnya dalam tindakan medis.

Hubungan hukum yang timbul antara dokter pasien dapat berupa hukum pidana, perdata dan administrasi negara. Hubungan hukum perdata antara dokter dan pasien adalah hubungan kontrak terapeutik, sehingga dalam hubungannya ini terbentuk perikatan yang muncul karena perjanjian, perjanjian yang dimaksud adalah pada saat pasien berobat kepada seorang dokter, maka dokter akan melakukan upaya untuk melakukan proses pengobatan kepada pasien. Seorang dokter tidak boleh menjanjikan hasil kepada pasien, tetapi menjanjikan upaya yang dilakukan. Jadi seorang dokter tidak dapat dituntut karena hasil yang tidak sesuai dengan yang diharapkan oleh pasien, namun dokter dapat dituntut jika telah melakukan upaya yang tidak sesuai dengan standar prosedur yang telah ditetapkan.

Dalam Pasal 3 Undang-Undang Republik Indonesia Nomor 29 Tahun 2004 tentang Praktik Kedokteran dijelaskan mengenai pengaturan praktik kedokteran yang betujuan: ${ }^{3}$

1. memberikan perlindungan kepada pasien;

2. mempertahankan dan meningkatkan mutu pelayanan medis yang diberikan oleh dokter dan dokter gigi;

\footnotetext{
1 Darwin, Eryati. Etika profesi kesehatan. Yogyakarta: Grup Penerbit CV Budi Utama; 2014

2 Veronika Komalawati. Hukum dan etika praktik dokter. Jakarta: Sinar Harapan; 1989

3 Undang- Undang Nomor 29 Tahun 2004 tentang Praktek Kedokteran
} 
SOEPRA Jurnal Hukum Kesehatan

TERAKREDITASI RISTEKDIKTI Peringkat 4

ISSN:2548-818X (media online) Vol. 7 (1) Juni 2021

3. memberikan kepastian hukum kepada masyarakat, dokter dan dokter gigi.

Undang-undang di atas telah memberikan kepastian hukum mengenai perlindungan pasien terhadap tindakan yang dilakukan oleh dokter. Selain itu juga menuntut agar dokter dalam melaksanakan profesinya selalu berupaya meningkatkan mutu pelayanan medis terhadap pasiennya. Dalam Undang-undang tersebut dijelaskan bahwa praktik kedokteran memberikan perlindungan kepada masyarakat, selain itu juga guna meningkatkan mutu pelayanan Kesehatan bagi masyarakat.

Dalam melaksanakan profesinya, seorang dokter mendapatkan autonomi penuh terhadap pasiennya. Namun, bukan berarti dokter dapat semena-mena terhadap pasien. Tidak semua orang dapat menjalankan profesi kedokteran karena harus yang memenuhi standar profesi untuk dapat menjalankan profesi kedokteran. Dalam memberikan pelayanan seorang dokter haruslah berupaya sebaik-baiknya demi kesembuhan pasiennya. Tidak seorang dokter pun yang memiliki niat yang buruk kepada pasiennya. Namun, dalam menjalankan profesinya seorang dokter dapat melakukan tindakan yang dapat merugikan pasiennya yang dilakukan tanpa sengaja yang disebabkan oleh kelalaian/kealpaan dokter tersebut. Perbuatan yang merugikan orang lain walaupun tanpa ada niat kepada korbannya dapat dikenai sanksi menurut peraturan perundang-undangan. ${ }^{4}$ Kelalaian dokter dalam memberikan pelayanan medis kepada pasiennya sehingga menimbulkan kerugian kepada pasien dapat menyebabkan sengketa medis. Namun, tidak selamanya sengketa medis disebabkan oleh kelalaian dokter karena sengketa medis dapat saja sebenarnya merupakan risiko medis. Sengketa medis jika tidak terpenuhinya kesepakatan oleh tenaga medis (wanprestasi) atau perbuatan melanggar hukum (onrechtmatige daad) yang menyebabkan kerugian terhadap pasien. Wanprestasi yang dilakukan dapat berupa tidak dilakukan sama sekali prestasi yang telah diperjanjikan, prestasi yang dilaksanakan di bawah standar yang diperjanjikan, prestasi dilakukan tidak sesuai dengan waktu yang diperjanjikan, dan prestasi yang dilakukan tidak sesuai dengan prestasi yang diperjanjikan.

Penyelesaian sengketa medis tidak selamanya harus selalu diselesaikan di pengadilan, tetapi juga dapat dilakukan di luar pengadilan. Adapun penyelesaian sengketa di luar pengadilan telah diatur dalam peraturan perundang-undangan yang berlaku di Indonesia. Oleh karena itu, penulis membuat penelitian dengan judul "Penyelesaian Sengketa Medik di Luar Pengadilan Menurut Peraturan Perundang-Undangan yang Berlaku di Indonesia

\section{PERUMUSAN MASALAH}

a. apa dasar hukum sengketa medik?

b. bagaimana penyelesaian sengketa medik menurut peraturan perundang- undangan yang berlaku di Indonesia?

Untuk menyelesaikan permasalahan dalam penelitian ini, kita harus mengetahui teori pertanggungjawaban. Menurut Kamus besar Bahasa Indonesia, pertanggungjawaban adalah suatu keadaan wajib menanggung segala sesuatu atau akibat yang timbul dari suatu perbuatan baik itu berupa kelalaian maupun kesalahan. ${ }^{5}$

\footnotetext{
4 M. Achadiat Crisdiono. Dinamika etika dan hukum kedokteran dalam tantangan zaman. Jakarta: Penerbit Buku Kedokteran; 2004

5 Kamus Besar Bahasa Indonesia.
} 
Hans Kelsen mengenai tanggung jawab hukum menyatakan bahwa "seseorang bertanggung jawab secara hukum atas suatu perbuatan tertentu atau bahwa dia memikul tanggung jawab hukum, subyek berarti bahwa dia bertanggung jawab atas suatu sanksi dalam hal perbuatan yang bertentangan. ${ }^{6}$ Menurut Hans Kelsen

“Kegagalan untuk melakukan kehati-hatian yang diharuskan oleh hukum disebut kekhilafan (negligence); dan kekhilafan biasanya dipandang sebagai satu jenis lain dari kesalahan (culpa), walaupun tidak sekeras kesalahan yang terpenuhi karena mengantisipasi dan menghendaki, dengan atau tanpa maksud jahat, akibat yang membahayakan."

\section{Roeslan Saleh menyatakan Bahwa: ${ }^{7}$}

"Dalam membicarakan tentang pertanggungjawaban pidana, tidaklah dapat dilepaskan dari satu dua aspek yang harus dilihat dengan pandangan-pandangan falsafah. Satu diantaranya adalah keadilan, sehingga pembicaraan tentang pertanggungjawaban pidana akan memberikan kontur yang lebih jelas. Pertanggung jawaban pidana sebagai soal hukum pidana terjalin dengan keadilan sebagai soal filsafat"

Sementara itu, menurut kamus hukum, tanggung jawab diistilahkan sebagai liability dan responsibility. Liability merujuk pada pertanggungjawaban hukum yaitu tanggung gugat akibat kesalahan yang dilakukan oleh subjek hukum, sedangkan responsibility merujuk pada tanggung jawab politik. Menurut Ridwan Hakim Liability merupakan istilah hukum yang luas yang menunjuk hampir semua karakter risiko atau tanggung jawab, yang pasti, yang bergantung atau yang mungkin meliputi semua karakter hak dan kewajiban secara aktual atau potensial seperti kerugian, ancaman, kejahatan, biaya atau kondisi yang menciptakan tugas untuk melaksanakan undang-undang. Responsibility berarti hal yang dapat dipertanggungjawabkan atas suatu kewajiban, dan termasuk putusan, keterampilan, kemampuan dan kecakapan meliputi juga kewajiban bertanggung jawab atas undangundang yang dilaksanakan. ${ }^{8}$

Konsep pertanggungjawaban pidana merupakan syarat-syarat bagi sesorang dijatuhi pertanggunggjawaban atas perbuatan yang dilakukannya. Pertanggungjawaban pidana tidak hanya memperhatikan terhadap masyarakat saja, namun juga perlu diperhatikan terhadap pembuat pidana tersebut. ${ }^{9}$ Menurut Galligan, institusi negara harus bisa memenuhi syarat-syarat pembuat pidana untuk mendapat celaan akibat pertanggungjawaban pidananya, apabila insitusi tersebut tidak bisa memenuhi syarat-syarat tersebut yang membuat pembuat pidana mendapaat celaan, maka telah gagal institusi negara tersebut dalam mencapai tujuannya. Terdapat dua teori dalam menentukan pertanggungjawaban pidana, yaitu: ${ }^{10,11}$

a. Teori monistis. Teori ini salah satunya dikemukakan oleh Simon yang merumuskan: "strafbaarfeit" sebagai eene strafbaar gestelde, onrechtmatige, met schuld in verband staande handeling van een torekeningvatbaar person"

\footnotetext{
6 Hans Kelsen (a), General Theory Of law and State, diterjemahkan oleh Somardi, Teori Umum Hukum dan Negara, Dasar-Dasar Ilmu Hukum Normatif Sebagai Ilmu Hukum Deskriptif Empirik,BEE Media Indonesia, Jakarta, 2007

7 Roeslan Saleh. "Pikiran-pikiran Tentang Pertanggungjawaban Pidana". Ghalia Indonesia. Jakarta. 2002, hlm. 10

8 HR. Ridwan, Hukum Administrasi Negara, Raja Grafindo Persada, Jakarta, 2006 hlm 337

9 Septa Candra, Pembaharuan Hukum Pidana: Konsep Pertanggungjawaban Pidana dalam Hukum Pidana Nasional yang Akan Datang, Jurnal Cita Hukum Vol 1 No 1,2013, Jakarta. hlm 41

${ }_{10} \mathrm{lbid}$. hlm 4

${ }^{11}$ Agus Rusianto. Tindak Pidana dan Pertanggungjawaban Pidana, Kencana, Jakarta, 2016, hlm 37-46
} 
[suatu perbuatan oleh hukum yang diancam dengan hukuman, bertentangan dengan hukum dilakukan oleh seseorang yang bersalah dan orang itu dianggap bertanggung jawab atas perbuatannya]

Menurut aliran monistis strafbaarfeit meliputi unsur subjektif maupun objektif. Unsur subjektif nya adalah pembuat pidananya, sementara unsur objektifnya adalah perbuatannya. Sehingga jika terjadi suatu perbuatan pidana, maka pembuat pidana dapat dicela. ${ }^{12}$ Menurut teori ini, kesalahan berkaitan dengan keadaan psikologis yang artinya ada hubungan antara keadaan metal/ psikis pembuat dengan perbuatan yang melawan hukum. Dari teori di atas, dapat disimpulkan bahwa penganut teori moistis tidak memisahkan antara tindak pidana dengan pertanggungjawaban pidana. ${ }^{13}$

b. Teori dualistis. Pandangan ini dikemukakan oleh Herman Kontorowicz dalam bukunya yang berjudul Tut Und Schuld, beliau berpandangan bahwa kesalahan merupakan sifat dari pada kelakuan, sehingga untuk adanya strafvoraussetzungen (syarat-syarat penjatuhan pidana terhadap pembuat) diperlukan pembuktian terlebih dahulu bahwa perbuatan tersebut adalah perbuatan pidana, setelah itu dibuktikan kesalahn subjektif pembuat. ${ }^{14}$ Menurut teori ini kesengajaan dan kealpaan merupakan bentuk- bentuk kesalahan yang merupakan unsur pertanggungjawaban pidana. ${ }^{15}$ Moeljatno memberikan pandangan yang memudahkan hakim dalam mengambil keputusan. Jika suatu perbuatan pidana tidak terbukti, maka putusannya adalah bebas, jika terbukti suatu perbuatan pidana, pembuat perbuatan pidana tersebut tidak dapat langsung di pidana. Harus dibuktikan terlebih dahulu apakah pembuat perbuatan pidana tersebut mampu untuk mempertanggungjawabkan perbuatannya. Jika pembuat ternyata tidak mampu bertanggungjawab atau dinyatakan tidak bersalah atau tidak lalai, ataupun ada alasan pemaaf, maka ia lepas dari segala tuntutan hukum (onslag van alle rechtsver volging). Dalam teori dualisme ini berlaku asas tiada pidana tanpa kesalahan (keine starfe ohne schuld). ${ }^{16}$

Menurut Utrecht dalam bukunya, menyatakan bahwa kesalahan selalu disamakan dengan pertanggungjawaban pidana, maksudnya adalah unsur kesalahan sama dengan unsur pertanggungjawaban pidana. Orang yang berbuat salah adalah orang yang mampu bertanggung jawab. ${ }^{17}$ Kemampuan untuk bertanggungjawab menurut pompe adalah: ${ }^{18}$

a. Pembuat dapat menguasai pemikirannya, keadaan psikis atau mental pelaku tidak terganggu

b. Pembuat mengetahui makna dan akibat dari perbuatannya

c. Pembuat dapat menentukan perbuatannya dengan pendapatnya.

Hubungan antara dokter dan pasien merupakan perjanjian atau kontrak terapeutik, seorang dokter memberikan janji upaya yang optimal dalam proses penyembuhan pasien. Seorang dokter dilarang untuk menjanjikan hasil kepada pasien, karena dalam melaksanakan profesinya, dokter hanya bisa melakukan upaya terbaik demi Kesehatan pasiennya. Dalam hal ini, dokter sebagai fasilitas pemberi layanan kesehatan harus memberikan standar

\footnotetext{
${ }^{12}$ Septa Candra. Op. Cit. hlm 41

13 Agus Rusianto. Op Cit. hlm 39

${ }^{14}$ Septa Candra. Op. Cit. hlm $41-42$

${ }^{15}$ Agus Rusianto. Op Cit. hlm 39

${ }^{16}$ Septa Candra. Op. Cit. hlm 42

${ }^{17}$ Agus Rusianto. Op Cit. hlm. 39

18 Ibid. hlm 39-40
} 
pelayanan dan standar prosedur yang maksimal kepada pasien. Hal ini dikarenakan dokter dan pasien memiliki kedudukan yang sama di hadapan hukum. ${ }^{19}$

Menurut Bahder Johan Nasution, ${ }^{20}$ transaksi antara dokter dan pasien berbeda dengan transaksi yang biasa dilakukan masyarakat. Menurut hukum, transaksi terapeutik memiliki objek upaya seorang dokter memberikan pelayanan dan pilihan terapi terbaik bagi pasien untuk kesembuhan pasien. Sebagaimana umumnya suatu perikatan dalam transaksi terapeutik juga terdapat pihak-pihak yang mengikatkan diri, yaitu dokter sebagai pemberi atau penyedia layanan kesehatan kepada pasien dan pasien sebagai penerima layanan kesehatan yang diberikan oleh dokter.

Menurut R. Subekti, suatu perjanjian adalah suatu peristiwa dimana seseorang berjanji kepada orang lain, atau dimana dua orang saling berjanji untuk melaksanakan sesuatu hal. ${ }^{21}$ R. Wirjono Prodjodikoro, menyatakan bahwa suatu perjanjian adalah suatu perbuatan hukum mengenai harta benda kekayaan antara dua pihak, dalam mana satu pihak berjanji atau dianggap berjanji untuk melakukan suatu hal atau untuk tidak melakukan sesuatu hal, sedangkan pihak lain berhak menuntut pelaksanaan janji itu. ${ }^{22}$ Perjanjian yang terbentuk antara dokter dan pasien adalah upaya optimal yang dilakukan oleh dokter.

Pasal 1313 KUH Perdata memberikan definisi bahwa perjanjian adalah suatu perbuatan yang dilakukan oleh satu orang atau lebih mengikatkan dirinya terhadap satu orang lain atau lebih.

Terdapat syarat- syarat agar suatu persetujuan dianggap sah. Syarat-syarat ini terdapat dalam Pasal 1320 KUH Perdata, yaitu:

1. Kesepakatan mereka yang mengikatan dirinya;

2. Kecakapan untuk membuat suatu perikatan;

3. Suatu pokok persoalan terentu;

4. Suatu sebab yang tidak terlarang.

Kesepakatan didalam perjanjian tidak boleh terjadi jika ada pemaksaan dan penipuan sebagaimana diatur dalam Pasal 1323 sampai dengan Pasal 1328 KUHPerdata. Kesepakatan antara dokter dan pasien dalam rangka melakukan upaya kesehatan pasien juga diatur dalam Pasal 39 Undang-Undang Praktik Kedokteran bahwa praktik kedokteran diselenggarakan berdasarkan pada kesepakatan antara dokter atau dokter gigi dengan pasien dalam upaya untuk pemeliharaan kesehatan, pencegahan penyakit, peningkatan kesehatan, pengobatan penyakit dan pemulihan kesehatan. Jadi kesepakatan yang muncul adalah kesepakatan tentang upaya, bukan kesepakatan hasil

Pasal 1330 KUHPerdata mengatur tentang pihak-pihak yang dianggap tidak cakap membuat perjanjian yaitu :

a. Orang-orang yang belum dewasa;

b. Mereka yang ditaruh di bawah pengampuan;

Dari penjelasan di atas, pasien yang bisa memberikan kesepakatan adalah pasien yang sudah dianggap dewasa dan tidak dalam bawah pengampuan. Jika pasien belum dewasa ataupun

\footnotetext{
19 Desriza Ratman. Aspek hukum penyelenggaraan prakek medokteran dan malpraktik medik. Bandung: Keni Media; 2014.

20 Bahder Johan Nasution, Hukum kesehatan pertanggungawaban dokter. Jakarta: Rineka Cipta; 2005.

${ }^{21}$ R.Subekti, Pokok-Pokok Hukum Perdata. Intermasa, Jakarta, 2001, hlm. 36

${ }^{22}$ R. Wirjono Prodjodikoro, Asas-Asas Hukum Perjanjian, PT. Bale, Bandung, 1986, hlm.9.
} 
dibawah pengampuan, maka yang bisa memberikan kesepakatan adalah keluarga atau wali pasien.

Suatu pokok persoalan tertentu dalam perjanjian antara dokter dan pasien adalah upaya penyembuhan. Seorang dokter tidak boleh menjanjikan kesembuhan kepada pasiennya. Tetapi seorang dokter harus berjanji akan melakukan upaya terbaiknya untuk kesembuhan pasiennya. Perjanjian upaya ini disebut Inspanning Verbntenis. ${ }^{23}$

Sebab yang halal adalah perjanjian yang dibuat tidak melanggar undang-undang, kesusilaan dan ketertiban umum. Hal ini diatur dalam Pasal 1337 KUHPerdata bahwa suatu sebab adalah terlarang, apabila dilarang oleh undang-undang, atau apabila berlawanan dengan kesusilaan baik atau ketertiban umum. Upaya yang dilakukan oleh dokter untuk kesembuhan pasiennya haruslah sesuai dengan standar minimal yang telah ditetapkan dan harus sesuai dengan peraturan Perundang-undangan yang berlaku.

Unsur dalam syarat sah perjanjian pada poin pertama dan kedua pada Pasal 1320 KUHPerdata merupakan unsur subjektif, sementara poin ketiga dan keempat merupakan unsur objektif. Unsur-unsur tersebut harus terpenuhi. Jika unsur subjektif tidak terpenuhi maka perjanjian dapat dibatalkan, namun jika unsur objektif yang tidak terpenuhi maka perjanjian batal demi hukum. ${ }^{24}$

Walaupun hubungan dokter pasien terus mengalami perkembangan, namun pada intinya tindakan dokter merupakan tindakan dalam pelayanan kesehatan. Dany Wiradharma mengutip pendapat Leenen yang menyatakan kewajiban dokter atau dokter gigi dalam melaksanakan pelayanan kesehatan dapat dibagi menjadi 3 kelompok, yaitu: ${ }^{25}$

1. Kewajiban yang timbul dari sifat perawatan medik dimana dokter harus bertindak sesuai dengan standar profesi medis atau menjalankan praktek kedokterannya secara lege artis;

2. Kewajiban untuk menghormati hak-hak pasien yang bersumber dari hak-hak asasi dalam bidang kesehatan;

3. Kewajiban yang berhubungan dengan fungsi sosial pemeliharaan kesehatan.

Menurut Brader Johan Nasution, dalam KUHPerdata dikenal adanya 2 (dua) macam perjanjian, yaitu : ${ }^{26}$

1. Inspanningverbintenis, yaitu perjanjian upaya, artinya kedua belah pihak yang berjanji berdaya upaya secara maksimal untuk mewujudkan apa yang diperjanjikan;

2. Resultaatverbintenis, yaitu suatu perjanjian bahwa pihak yang berjanji akan memberikan suatu resultaat, yaitu suatu hasil yang nyata sesuai dengan apa yang diperjanjikan.

Jika dilihat dari pembagian perjanjian di atas, hubungan keperdataan dokter-pasien adalah Inspanningverbintenis, dimana seorang dokter menjanjikan upaya pelayanan kesehatan terhadap keluhan penyakit pasiennya berdasarkan keilmuan kedokteran yang dimilikinya.

\footnotetext{
${ }^{23}$ Syahrul Machmud. Penegakan Hukum dan Perlindungan Hukum Bagi Dokter Yang Diduga Melakukan Medikal Malpraktek, Karya Putra Darwati, Bandung, 2012, hlm 70

24 Bernadeta Resta Nurhayati, Penyalahgunaan Keadaan Sebagai Dasar Pembatalan Perjanjian, Jurnal Komunikasi Hukum Vol 5 No 1,2019, hlm 4

25 Danny Wiradharma, Penuntun Kuliah Hukum Kedokteran, Bina Rupa Aksara, Jakarta, 1996, hlm 74

${ }^{26}$ Bader Johan Nasution, Hukum Kesehatan (PertanggungJawaban Dokter), Rineka Cipta, Jakarta, 2005, hlm 13
} 
Seorang dokter tidak boleh menjanjikan hasil terhadap pelayanan kesehatan yang diberikannya. ${ }^{27}$

Dalam hubungan dokter- pasien, diatur hak dan kewajiban masing- masing. Pasal 52 Undang- undang Praktik Kedokteran, menjelaskan bahwa pasien dalam menerima pelayanan pada praktik kedokteran, mempunyai hak sebagai berikut:

1. Mendapatkan penjelasan secara lengkap tentang tindakan medis sebagaimana dimaksud dalam Pasal 45 ayat (3).

2. Meminta pendapat dokter atau dokter gigi lain.

3. Mendapatkan pelayanan sesuai dengan kebutuhan medis.

4. Menolak tindakan medis. dan

5. Mendapatkan isi rekam medis.

Sementara Kewajiban pasien diatur pada Pasal 53 UU Praktik Kedokteran, yaitu:

1. Memberikan informasi yang lengkap dan jujur tentang masalah kesehatannya, artinya bahwa pasien wajib memberikan informasi baik identitas maupun riwayat penyakit serta keluhan yang dirasa pasien dengan jujur dan sebenar-benarnya tanpa ada yang disembunyikan dari dokter.

2. Mematuhi nasihat dan petunjuk dokter atau dokter gigi, artinya bahwa pasien wajib menjalankan aturan-aturan baik berupa nasihat maupun petunjuk yang diberikan oleh dokter sebagai upaya penyembuhan bagi pasien.

3. Mematuhi ketentuan yang berlaku di sarana pelayanan kesehatan; dan Memberikan imbalan jasa atas pelayanan yang diterima.

\section{METODE PENELITIAN}

Penelitian ini merupakan penelitian yuridis-normatif. Penelitian ini mendeskripsikan penyelesaian sengketa medik di Indonesia berdasar atas peraturan perundang-undangan yang berlaku di Indonesia. Kemudian, menganalisis setiap pilihan penyelesaian sengketa medik yang terdapat di peraturan perundang-undangan. Data yang digunakan dalam penelitian ini adalah data sekunder yang terdiri atas bahan hukum primer (perundangundangan), bahan hukum sekunder (doktrin), dan bahan hukum tersier (opini masyarakat).

Objek pada penelitian ini adalah penyelesaian sengketa medik di Indonesia. Penelitian ini merupakan penelitian kepustakaan, bahan-bahannya diambil dari kepustakaan yang telah ada dan peraturan perundang-undangan yang berlaku.

Tahap penelitian yang dilakukan oleh peneliti meliputi penelitian kepustakaan dengan tahapan sebagai berikut:

1. tahap persiapan, yaitu tahap merancang desain penelitian yang akan dilakukan dengan kegiatan penelitian;

2. tahap penelitian, yaitu tahap pengumpulan data melalui studi kepustakaan (literatur dan dokumen) yang berhubungan dengan penelitian ini;

3. tahap tenyusunan atau pembuatan laporan ahkir.

Bahan hukum yang dikaji dan yang dianalisis dalam penelitian hukum normatif, meliputi bahan hukum primer, sekunder, dan tersier. Teknik untuk mengkaji dan mengumpulkan

\footnotetext{
27 Safitri Hariyani, Sengketa Medik (Alternatif PenyelesaianPerselisihan Antara Dokter Dengan Pasien), Diadit Media, Jakarta, 2005, hlm 14
} 
ketiga bahan hukum itu, yaitu menggunakan studi dokumenter. Penelitian ini menggunakan pendekatan yuridis normatif. Pendekatan yuridis normatif adalah pendekatan atau penelitian hukum dengan menggunakan metode analisis yang termasuk dalam disiplin ilmu hukum yang dogmatis.

Peraturan Perundang-undangan yang digunakan dalam penelitian ini adalah:

1. Kitab Undang-Undang Hukum Perdata,

2. Kitab Undang-Undang Hukum Pidana

3. Herzien Inlandsch Reglement

4. Undang-Undang No. 8 tahun 1999 tentang Perlindungan Konsumen

5. Undang-undang No. 30 Tahun 1999 tentang Arbitrase dan Alternatif Penyelesaian Sengketa

6. Undang-undang No. 29 tahun 2004 tentang Praktik Kedokteran

7. Undang-Undang No. 36 tahun 2009 tentang Kesehatan

8. Peraturan Mahkamah Agung No. 1 Tahun 2008 tentang Mediasi

Analisis data penelitian ini adalah menguraikan secara sistematis dan konsisten terhadap penyelesaian sengketa medik sesuai dengan peraturan perundang-undangan yang berlaku. Analisis menggunakan logika dedukatif, logika yang bertolak dari "umum ke khusus"

\section{PEMBAHASAN}

Pertanggungjawaban hukum dokter dapat dilihat dari hukum perdata, hukum pidana, dan juga hukum administratif. Dari segi hukum perdata, pasien dapat mengajukan gugatan kepada dokter karena perbuatan melanggar hukum (onrechmatige daad). Pertanggungjawaban karena kesalahan merupakan bentuk klasik dalam hukum perdata.

Pertanggungjawaban ini diatur dalam Pasal 1365, 1366, 1367 Kitab Undang-Undang Hukum Perdata.

\section{Pasal 1365 KUHPer:}

"Tiap perbuatan melanggar hukum, yang membawa kerugian kepada orang lain, mewajibkan orang yang karena salahnya menerbitkan kesalahan itu, mengganti kerugian tersebut."

\section{Pasal 1366 Kitab Undang-Undang Hukum Perdata:}

"Setiap orang bertanggung jawab tidak saja untuk kerugian yang disebabkan karena perbuatannya, tetapi juga untuk kerugian yang disebabkan karena kelalaian atau kurang hati-hatinya"

\section{Pasal 1367 Kitab Undang-Undang Hukum Perdata:}

"seseorang tidak hanya bertanggungjawab atas kerugian yang disebabkan perbuatannya sendiri, melainkan juga atas kerugian yang disebabkan perbuatan orangorang yang menjadi tanggungannya atau disebabkan barang-barang yang berada dalam pengawasannya"

Pasal 1365 KUHPer menjelaskan pertanggung jawaban bagi orang yang telah melanggar hukum dan akibat perbuatannya itu menyebabkan kerugian pada orang lain. Menurut yurisprudensi tahun 1919 perbuatan melawan hukum adalah setiap tindakan atau kelalaian yang $^{18}$ 
1. melanggar hak orang lain;

2. bertentangan dengan kewajiban hukum diri sendiri;

3. menyalahi pandangan etis yang umumnya dianut (adat istiadat yang baik)

4. tidak sesuai dengan kepatuhan dan kecermatan sebagai persyaratan tentang diri dan benda orang seorang dalam pergaulan hidup

Pelanggaran dokter terhadap pasien bisa berupa hak pasien yang tidak dipenuhi, dokter melakuka tindakan yang tidak sesuai dengan hukum yang berlaku, seperti melakukan abortus yang tidak sesuai indikasi, dokter melakukan tindakan yang melanggar etika profesi, atau dalam melaksanakan tindakan medis, seorang dokter tidak sesuai dengan Standar prosedur minimal yang berlaku.

Menurut Abdulkadir Muhammad teori tanggung jawab dalam perbuatan melanggar hukum (tort liability) dibagi menjadi beberapa teori: ${ }^{28}$

a. Tanggung jawab akibat perbuatan melanggar hukum yang dilakukan dengan sengaja (intertional tort liability), tergugat harus sudah melakukan perbuatan sedemikian rupa sehingga merugikan penggugat atau mengetahui bahwa apa yang dilakukan tergugat akan mengakibatkan kerugian.

b. Tanggung jawab akibat perbuatan melanggar hukum yang dilakukan karena kelalaian (negligence tort lilability), didasarkan pada konsep kesalahan (concept of fault) yang berkaitan dengan moral dan hukum yang sudah bercampur baur (interminglend).

c. Tanggung jawab mutlak akibat perbuatan melanggar hukum tanpa mempersoalkan kesalahan (stirck liability), didasarkan pada perbuatannya baik secara sengaja maupun tidak sengaja, artinya meskipun bukan kesalahannya tetap bertanggung jawab atas kerugian yang timbul akibat perbuatannya

Dalam pertanggungjawaban hukum juga dikenal konsep vicarious liability yaitu pertanggungjawaban seseorang atas kesalahan yang dilakukan oleh orang lain. Vicarious liability ini sebenarnya diterapkan dalam hukum perdata, namun diaplikasikan juga dalam hukum pidana. Secara umum, vicarious liability ini diterapkan tanggungjawab majikan terhadap Tindakan yang dilakukan oleh karyawannya dalam ruang lingkup pekerjaannya.

Peraturan perundang-undangan secara eksplisit menyebutkan vicarious liability

1. Pengadilan mengembangkan "doktrin pendelegasian" dalam kasus pemberian lisensi

2. Pengadilan dapat menginterpretasikan kata- kata dalam undang-undang sehingga Tindakan dari pekerja atau pegawai merupakan Tindakan dari perusahaan.

Terdapat dua syarat yang harus dipenuhi untuk menerapkan vicarious liability dalam Tindakan pidana, yaitu: ${ }^{29}$

1. Harus terdapat hubungan, seperti majikan dengan pegawainya

2. Tindakan pidana yang dilakukan merupakan ruang lingkup pekerjaan perusahaan.

Seseorang yang telah dinyatakan telah melakukan kesalahan oleh hakim, namun karena pertimbangan lain hakim dapat memaafkan tindakan sipembuat selama kesalahan yang dilakukan oleh sipembuat merupakan Tindakan pidana ringan. Asas ini disebut Rechterlijke

\footnotetext{
${ }^{28}$ Abdulkadir Muhammad, Hukum Perusahaan Indonesia, Citra Aditya Bakti, 2010Gianfranco Poggi, The Development oh the Modern State "Sociological Introduction, Standford University Press, California, 1992 29 lbid hlm 51
} 
Pardon ${ }^{30}$ Kewenangan hakim dalam memaafkan perlu diimbangi pula dengan adanya asas culpa in causa atau asas actio libera in causa, yang memberi kewenangan kepada hakim untuk tetap mempertanggungjawabkan si pelaku tindak pidana walaupun ada alasan penghapus pidana, jika si pelaku patut dipersalahkan atau dicela atas terjadinya keadaan yang menjadi alasan penghapus pidana tersebut. ${ }^{31}$ Pembahasan pertanggungjawaban di atas merupakan pertanggungjawaban yang ditanggungkan kepada individu. Selain individu, dengan perkembangan pereknomian dan bisnis, korporasi juga dapat dijadikan sebagai subjek hukum.

Menurut Brader Johan Nasution, dalam KUHPerdata dikenal 2 (dua) macam perjanjian. ${ }^{32}$

1. Inspanningverbintenis, yaitu perjanjian upaya, artinya kedua belah pihak yang berjanji berdaya upaya secara maksimal untuk mewujudkan apa yang diperjanjikan.

2. Resultaatverbintenis, yaitu suatu perjanjian bahwa pihak yang berjanji akan memberikan suatu resultaat, yaitu suatu hasil yang nyata sesuai dengan apa yang diperjanjikan.

Penjelasan Brader Johan di atas, perjanjian yang tercipta antara dokter-pasien adalah Inspanningverbintenis, sehingga dokter harus memberikan upaya yang maksimal. Dokter dianggap salah jika dalam upaya pelayanan kesehatannya tidak sesuai dengan standar minimal. Namun, jika hasil yang diharapkan tidak sesuai dengan yang diharapkan, maka dokter tidak bisa dianggap melakukan tindakan kesalahan. Sehingga jika pasien ingin menuntut dokter, dokter tersebut harus melakukan kesalahan dalam prosedurnya, bukan hasil yang tidak sesuai.

Unsur-unsur yang terdapat pada Pasal 1365 KUHPerdata dalam sengketa medik:

1. Adanya melanggar hukum

2. Adanya kesalahan dokter dalam melakukan prosedur medis

3. Adanya kerugian yang dialami oleh pasien.

Jika Pada pasal 1365 KHUPer karena kesalahan dokter, maka pada Pasal 1366 KUHPer menjelaskan dokter dapat dituntut secara perdata karena kelalaiannya. Hal ini sesuai dengan penjelasan Abdulkadir Muhammad mengenai tanggung jawab mengenai melanggar hukum yang telah dijelaskan di atas.

Pada pasal 13667 KUHPer menjelaskan pertanggungjawaban karena kesalahan atau kelalaian yang dilakukan oleh orang lain. Dalam pertanggungjawaban hukum juga dikenal konsep vicarious liability yaitu pertanggungjawaban seseorang atas kesalahan yang dilakukan oleh orang lain. Vicarious liability ini sebenarnya diterapkan dalam hukum perdata, namun diaplikasikan juga dalam hukum pidana. Secara umum, vicarious liability ini diterapkan tanggungjawab majikan terhadap Tindakan yang dilakukan oleh karyawannya dalam ruang lingkup pekerjaannya. ${ }^{20}$ Dari Pasal ini dapat dijelaskan bahwa seorang dokter dapat dimintakan pertanggungjawabannya walaupun yang membuat kesalahan atau kelalaian adalah perawat, selama kesalahan atau kelalaian perawat tersebut merupakan pekerjaan yang di suruh oleh dokter.

Pasien yang merasa dirugikan oleh dokter, dapat melakukan penuntutan kepada dokter untuk mempertanggungjawabkan perbuatannya terhadap pasien. Jika pasien merasa dokter tersebut telah melakukan wanprestasi, maka pasien dapat melakukan penuntutan

\footnotetext{
$30 \mathrm{Ibid} \mathrm{hlm} 53$

${ }^{31} \mathrm{lbid}$ hlm 53

32 Bahder Johan Nasution. Op Cit
} 
secara perdata. Menurut Pasal $130 \mathrm{HIR}$, seorang hakim wajib mendamaikan para pihak berpekara sebelum dimulai persidangan. Namun HIR tidak mengatur bagaimana mekanisme tersebut dilaksanakan. Peraturan Mahkamah Agung No. 1 Tahun 2008 tentang Mediasi telah memberikan pedoman kepada hakim tentang mekanisme dalam mendamaikan para pihak berperkara.

Undang-undang No. 30 Tahun 1999 tentang Arbitrase dan Alternatif Penyelesaian Sengketa menjelaskan tentang beberapa alternatif penyelesaian sengketa di luar pengadilan. Pada Pasal 1 angka 10 disebutkan bahwa alternatif penyelesaian sengketa adalah Lembaga penyelesaian sengketa atau beda pendapat melalui prosedur yang disepakati para pihak, yakni penyelesaian di luar pengadilan dengan cara konsultasi, negosiasi, mediasi, konsiliasi dan penilaian ahli.

Menurut Chistopher W. Moor terdapat beberapa kelebihan mekanisme Alternatif Penyelesaian Sengketa disbanding dengan pengadilan, di antaranya adalah:33

1. sifat kesukarelaan dalam proses;

2. prosedur yang cepat;

3. keputusan non judicial;

4. kontrol oleh manajer yang paling tahu mengenai kebutuhan organisasi;

5. prosedur Rahasia;

6. fleksibilitas dalam merancang syarat-syarat penyelesaian masalah;

7. hemat waktu;

8. hemat biaya;

9. kemungkinan untuk melaksanakan kesepakatan tinggi;

Selain kelebihan, Alternatif Penyelesaian Sengketa juga memiliki beberapa kekurangan, di antaranya adalah: ${ }^{22}$

1. tidak memperjuangkan hak-hak minoritas;

2. mediator atau abiter tidak dapat memkasakan para pihak untuk hadir dan memaksakan hasil putusan;

3. tidak semua kasus dapat diselesaikan melalui Alternatif Penyelesaian sengketa;

4. keefektifan penggunaan Alternatif Penyelesaian Sengketea di negara-negara berkembang dipertanyakan;

5. mediasi sulit dijalankan jika para pihak berada pada strata yang berbeda;

6. sifat rahasia menyebabkan publik tidak dapat melakukan kontrol terhadap jalannya persidangan.

Dari penjelasan di atas, bahwa alternatif penyelesaian sengketa terdiri atas:34 3536

1. konsultasi. Menurut Black's Law Dictionary, konsultasi (consultation) adalah, "Act of consulting or conferring: e.g. patient with doctor, client with lawyer. Deliberation of persons on some subject." Prinsipnya adalah konsultasi merupakan Tindakan yang bersifat interpersonal untuk meminta pendapat ahli mengenai sengketa yang dihadapi. Misalnya pada kasus sengketa medis, pasien dapat meminta pendapat ahli baik dibidang kedokteran maupun bidang hukum untuk mendapatkan solusi yang terbaik bagi keduabelah pihak. Namun apa yang disampaikan ahli tersebut tidak bersifat

33 Agus Rusianto. Tindak pidana dan pertanggungjawaban pidana. Jakarta; Kencana; 2016

34 Nevey Varida Ariani. “Alternatif penyelesaian sengketa bisnis di luar pengadilan,” jurnal Rechtsvinding.2012; 1 (2)

35 Idris Talib. Bentuk putusan penyelesaian sengketa berdasarkan mediasi. Lex et Societatis, 2013 Jan-Mar; 1(1)

36 Hilman Syahrial haq. Mediasi komunitas sebagai APS.. Lakeisha. 2019 
memaksa. Untuk keputusan tetap berada ditangan pihak yang berkonsultasi. Dalam konsultasi ini, pihak tergugat yang paling menentukan, karena apapun yang dikonsultasikan tetapi tetap pihak yang meminta konsultasi yang menentukan apakah akan tetap melanjutkan perkara atau tidak.

2. negosiasi. Marwan dan Jimmy $P$, mengartikan negosiasi sebagai proses tawarmenawar dengan jalan berunding antara para pihak yang bersengketa untuk mencapai kesepakatan bersama. Negosiasi merupakan bentuk perundingan bagi para pihak dengan jalan damai untuk mencapai suatu kesepakatan. Dalam negosiasi ini yang terlibat pihak yang bersengketa saja tanpa melibatkan pihak ketiga. Dalam proses negosiasi ini akan terjadi proses tawar menawar antara kedua belah pihak sehingga terbentuk opsi-opsi dalam menyelesaikan sengketa. Hasil kesepakatan ini harus dibuat dalam bentuk tertulis yang kemudian harus didaftarkan ke dalam pengadilan untuk mendapatkan kepastian hukum yang mengikat.

3. mediasi. Berdasarkan PERMA No. 1 Tahun 2016 menjelaskan bahwa mediasi adalah cara penyelesaian sengketa melalui proses perundingan untuk memperoleh kesepakatan para pihak dengan dibantu mediator, yaitu hakim atau pihak lain yang memiliki sertifikat mediator, sebagai pihak yang netral tanpa memaksakan keputusan mediator. Mediator hanya berperan sebagai perantara yang memberikan berbagai pandangan mengenai beberapa kemungkinan yang akan diambil. Yang membedakannya dengan negosiasi adalah pihak ketiga dalam proses perdamaian. Mediator harus bersifat netral, dia bertugas sebagai penengah bagi para pihak dan memberikan pandanganpandangannya kepada para pihak sehingga muncul kesepakatan untuk perdamaian.

4. konsiliasi. Istilah konsiliasi dalam bahasa Inggris disebut sebagai "Conciliation", M. Marwan dan Jimmy $P$, mengartikan konsiliasi sebagai upaya untuk mempertemukan keinginan pihak-pihak bersengketa agar mencapai kesepakatan guna menyelesaikan sengketa dengan kekeluargaan. Sementara Munir Fuady menjelaskan, konsiliasi mirip dengan mediasi, yakni merupakan proses penyelesaian sengketa berupa negosiasi untuk memecahkan masalah melalui pihak luar yang netral dan tidak memihak yang akan bekerja dengan pihak yang bersengketa untuk membantu menemukan solusi dalam menyelesaikan sengketa tersebut;

5. penilaian ahli. Penilaian ahli merupakan pendapat ahli terhadap suatu perkara yang dapat diterima oleh para pihak. Penilaian ahli sama dengan saksi ahli. Pasal 1 angka 28 Undang-undang No. 8 tahun 1981 tentang Kitab Hukum Acara Pidana (KUHAP) dirumuskan bahwa "Keterangan ahli adalah keterangan yang diberikan oleh seorang yang memiliki keahlian khusus tentang hal yang diperlukan untuk membuat terang suatu perkara pidana guna kepentingan pemeriksaan". Perbedaan antara penilaian ahli dan saksi ahli terletak pada prosesnya, penilaian ahli diberikan di luar pengadilan sementara keterangan ahli diberikan di dalam pengadilan.

Pada pasal 29 Undang-undang No. 29 Tahun 2004 tentang Kesehatan, setiap sengketa yang timbul sebagai akibat kelalaian tenaga kesehatan harus diselesaikan terlebih dahulu melalui mekanisme mediasi. Pada undang-undang ini sangat jelas bahwa, jika ada pihak yang merasa dirugikan maka sebaiknya diselesaikan terlebih dahulu secara mediasi.

Sementara jika pasien merasa seorang dokter telah melakukan perbuatan yang mengakibatkan cedera (baik cedera ringan maupun berat) bahkan kematian maka pasien dapat menuntut dokter tersebut secara pidana. Dalam Hukum Acara Pidana sebenarnya tidak mengenal alternatif penyelesaian sengketa sehingga setiap pelaku tindak pidana 
harus diproses sesuai dengan aturan yang berlaku. Namun demikian, pada praktik di lapangan sering juga kasus-kasus pidana diselesaikan di luar pengadilan melalui diskresi aparat penegak hukum ataupun melalui musyawarah. ${ }^{21}$

Mediasi penal merupakan salah satu jalan yang dapat ditempuh untuk kasus dugaan malpraktik sebagai alternatif penyelesaian sengketa di luar pengadilan. Mediasi penal muncul dari wacana restorative justice yang berupaya mengakomodir korban dan pelaku tindak pidana. Serta mencari solusi terhadap sengketa antara korban dan pelaku. Pada mediasi penal ini, menempatkan peradilan sebagai mediator.

Mudzakkir mengemukakan beberapa perkara pidana yang dapat diselesaikan melalui mediasi penal, yaitu ${ }^{26}$

1. pelanggaran hukum pidana tersebut merupakan delik aduan;

2. pelanggaran hukum pidana tersebut merupakan pidana denda sebagai ancaman pidana dan telah dibayarkan pelaku (Pasal 80 KUHP);

3. pelanggaran hukum pidana tersebut termasuk kedalam "pelanggaran" bukan sebuah "kejahatan";

4. pelanggaran hukum pidana tersebut termasuk pidana dibidang hukum administrasi yang menempatkan pidana sebagai ultimum remedium;

5. pelanggaran hukum pidana biasa yang dihentikan atau tidak diproses ke pengadilan (deponir) oleh jaksa agung sesuai dengan kewenangan hukum yang dimilikinya;

6. pelanggaran hukum pidana tersebut merupakan pelanggaran hukum pidana adat yang dapat diselesaikan melalui Lembaga adat.

Di Indonesia juga berlaku penyelesaian permasalahan pidana secara musyarawarah jika tindak pidana tersebut termasuk ke dalam tindak pidana ringan. Penyelesaian secara musyawarah juga dapat memberikan rasa keadilan kepada kedua belah pihak, baik korban maupun pelaku tindak pidana. ${ }^{27}$

Jika dilihat dari penjelasan di atas, penyelesaian dugaan malpraktik dapat diselesaikan secara mediasi penal maupun musyawarah jika termasuk ke dalam tindak pidana ringan. Misalnya cedera yang dihasilkan merupakan cedera ringan yang dapat disembuhkan serta tidak mengancam jiwa.

Adapun beberapa Lembaga yang diamanatkan oleh undang-undang untuk menyelesaikan sengketa medik di luar pengadilan: ${ }^{28}$

1. Majelis Kehormatan Disiplin Kedokteran Indonesia (MKDKI). Lembaga MKDKI dibentuk berdasar atas amanat Undang-Undang No. 29 Tahun 2004 tentang Praktik Kedokteran. Pasal 55 ayat (1) UU Praktik Kedokteran menjelaskan bahwa MKDKI dibentuk dengan tujuan menegakkan disiplin dokter dan dokter gigi dalam menyelenggarakan praktik kedokteran. MKDKI memiliki tugas untuk menerima pengaduan, memeriksa dan memutuskan apakah seorang dokter melakukan pelanggaran disiplin atau tidak;

2. Majelis Kehormatan Etika Kedokteran (MKEK). Majelis Kehormatan Etika Kedokteran ini berada di bawah naungan Ikatan Dokter Indonesia (IDI). Sesuai dengan namanya, MKEK memiliki tugas melakukan pemeriksaan terhadap dokter yang diduga melakukan pelanggaran etika dalam melaksanakan tugas profesinya. Pada Pasal 68 Undangundang praktik Kedokteran menjelaskan bahwa MKEK melaksanakan pemeriksaan pelanggaran etika kedokteran setelah mendapat pelimpahan perkara dari MKDKI 
3. Badan Penyelesaian Sengketa Konsumen BPSK. Pada dasarnya BPSK menyelesaikan sengketa antara pelaku usaha dan konsumen. Dalam Undang-Undang No. 8 tahun 1999 tentang Perlindungan Konsumen disebutkan salah satu sektor yang diselesaikan sengketanya oleh BPSK adalah sektor kesehatan. Konsumen disektor kesehatan adalah pasien, sehingga jika terdapat sengketa antara pasien dan dokter maupun pihak rumah sakit, maka penyelesaian dapat dilakukan melalui BPSK. Penyelesaian sengketa melalui BPSK melalui 3 pilihan mekanisme, yaitu arbitrase, konsiliasi, atau mediasi. BPSK memiliki kewenangan untuk memberikan keputusan terhadap sengketa.

Peraturan perundang-undangan adalah urutan peraturan yang berlaku di Inonesia. Dalam peraturan ini menganut prinsip peraturan yang lebih rendah tidak boleh bertentangan dengan peraturan yang yang lebih tinggi. Jika terjadi bertentangan maka yang digunakan adalah peraturan yang lebih tinggi.

Mengenai peraturan perundang-undangan yang berlaku di Indonesia diatur dalam pasal 7 Undang-Undang No 12 Tahun 2011 tentang Peraturan Perundang- undangan: Jenis dan hierarki Peraturan Perundang-undangan terdiri atas:

a. Undang-Undang Dasar Negara Republik Indonesia Tahun 1945;

b. Ketetapan Majelis Permusyawaratan Rakyat;

c. Undang-Undang/Peraturan Pemerintah Pengganti Undang-Undang;

d. Peraturan Pemerintah;

e. Peraturan Presiden;

f. Peraturan Daerah Provinsi; dan

g. Peraturan Daerah Kabupaten/Kota.

\section{KESIMPULAN}

1. malpraktik medik secara hukum dapat dilihat beberapa aspek, yaitu

a. hukum perdata jika pasien merasa dokter telah melakukan wanprestasi

b. hukum pidana jika dokter melakukan kelalaian yang mengakibatkan cedera dan atau kematian pasien

c. hukum administratif jika dokter dalam melaksanakan pelayanan medis tidak memiliki STR ataupun SIP

2. penyelesaian sengketa medik dari segi Hukum Perdata dapat dilakukan di luar pengadilan melalui beberapa mekanisme, yaitu

1. konsultasi. Menurut Black's Law Dictionary, konsultasi (consultation) adalah, "Act of consulting or conferring: e.g. patient with doctor, client with lawyer. Deliberation of persons on some subject." Prinsipnya adalah konsultasi merupakan Tindakan yang bersifat interpersonal untuk meminta pendapat ahli mengenai sengketa yang dihadapi. Misalnya pada kasus sengketa medis, pasien dapat meminta pendapat ahli baik dibidang kedokteran maupun bidang hukum untuk mendapatkan solusi yang terbaik bagi keduabelah pihak. Namun apa yang disampaikan ahli tersebut tidak bersifat memaksa. Untuk keputusan tetap berada ditangan pihak yang berkonsultasi. Dalam konsultasi ini, pihak tergugat yang paling menentukan, karena apapun yang dikonsultasikan tetapi tetap pihak yang meminta konsultasi yang menentukan apakah akan tetap melanjutkan perkara atau tidak.

2. negosiasi. Marwan dan Jimmy $P$, mengartikan negosiasi sebagai proses tawarmenawar dengan jalan berunding antara para pihak yang bersengketa untuk mencapai kesepakatan bersama. Negosiasi merupakan bentuk perundingan bagi 
para pihak dengan jalan damai untuk mencapai suatu kesepakatan. Dalam negosiasi ini yang terlibat pihak yang bersengketa saja tanpa melibatkan pihak ketiga. Dalam proses negosiasi ini akan terjadi proses tawar menawar antara kedua belah pihak sehingga terbentuk opsi-opsi dalam menyelesaikan sengketa. Hasil kesepakatan ini harus dibuat dalam bentuk tertulis yang kemudian harus didaftarkan ke dalam pengadilan untuk mendapatkan kepastian hukum yang mengikat.

3. mediasi. Berdasarkan PERMA No. 1 Tahun 2016 menjelaskan bahwa mediasi adalah cara penyelesaian sengketa melalui proses perundingan untuk memperoleh kesepakatan para pihak dengan dibantu mediator, yaitu hakim atau pihak lain yang memiliki sertifikat mediator, sebagai pihak yang netral tanpa memaksakan keputusan mediator. Mediator hanya berperan sebagai perantara yang memberikan berbagai pandangan mengenai beberapa kemungkinan yang akan diambil. Yang membedakannya dengan negosiasi adalah pihak ketiga dalam proses perdamaian. Mediator harus bersifat netral, dia bertugas sebagai penengah bagi para pihak dan memberikan pandangan-pandangannya kepada para pihak sehingga muncul kesepakatan untuk perdamaian.

4. konsiliasi. Istilah konsiliasi dalam bahasa Inggris disebut sebagai "Conciliation", M. Marwan dan Jimmy P, mengartikan konsiliasi sebagai upaya untuk mempertemukan keinginan pihak-pihak bersengketa agar mencapai kesepakatan guna menyelesaikan sengketa dengan kekeluargaan. Sementara Munir Fuady menjelaskan, konsiliasi mirip dengan mediasi, yakni merupakan proses penyelesaian sengketa berupa negosiasi untuk memecahkan masalah melalui pihak luar yang netral dan tidak memihak yang akan bekerja dengan pihak yang bersengketa untuk membantu menemukan solusi dalam menyelesaikan sengketa tersebut;

5. penilaian ahli. Penilaian ahli merupakan pendapat ahli terhadap suatu perkara yang dapat diterima oleh para pihak. Penilaian ahli sama dengan saksi ahli. Pasal 1 angka 28 Undang-undang No. 8 tahun 1981 tentang Kitab Hukum Acara Pidana (KUHAP) dirumuskan bahwa "Keterangan ahli adalah keterangan yang diberikan oleh seorang yang memiliki keahlian khusus tentang hal yang diperlukan untuk membuat terang suatu perkara pidana guna kepentingan pemeriksaan". Perbedaan antara penilaian ahli dan saksi ahli terletak pada prosesnya, penilaian ahli diberikan di luar pengadilan sementara keterangan ahli diberikan di dalam pengadilan.

Terdapat beberapa Lembaga untuk menyelesaikan sengketa medik di luar pengadilan, di antaranya adalah:

a. Majelis Kehormatan Disiplin Kedokteran Indonesia;

b. Majelis Kehormatan Etika Kedokteran;

c. Badan Penyelesaian Sengketa Medik.

\section{Saran}

1. Perlu aturan khusus yang mengatur malpraktik sehingga memberikan kepastian hukum kepada pasien maupun dokter dalam pelayanan Kesehatan

2. Perlu lembaga peradilan ad hoc khusus yang lebih cepat dan sederhana dibanding dengan lembaga peradilan umum untuk menyelesaikan sengketa medis sehingga setiap pasien yang merasa dirugikan oleh dokter dapat mendapatkan keadilan lebih cepat. Selain itu, juga memberikan kepastian hukum kepada dokter.

3. Pada penelitian berikutnya, perlu dikaji lebih dalam kelebihan dan kekurangan masingmasing alternatif penyelesaian sengketa medik di luar pengadilan 


\section{DAFTAR PUSTAKA}

Abdulkadir Muhammad, Hukum Perusahaan Indonesia, Citra Aditya Bakti, 2010Gianfranco Poggi, The Development oh the Modern State "Sociological Introduction, Standford University Press, California, 1992

Agus Rusianto. Tindak pidana dan pertanggungjawaban pidana. Jakarta; Kencana; 2016

Bahder Johan Nasution, Hukum kesehatan pertanggungawaban dokter. Jakarta: Rineka Cipta; 2005.

Bernadeta Resta Nurhayati, Penyalahgunaan Keadaan Sebagai Dasar Pembatalan Perjanjian, Jurnal Komunikasi Hukum Vol 5 No 1,2019

Danny Wiradharma, Penuntun Kuliah Hukum Kedokteran, Bina Rupa Aksara, Jakarta, 1996, hlm 74

Darwin, Eryati. Etika profesi kesehatan. Yogyakarta: Grup Penerbit CV Budi Utama; 2014

Desriza Ratman. Aspek hukum penyelenggaraan prakek medokteran dan malpraktik medik. Bandung: Keni Media; 2014.

Hans Kelsen (a), General Theory Of law and State, diterjemahkan oleh Somardi, Teori Umum Hukum dan Negara, Dasar-Dasar Ilmu Hukum Normatif Sebagai Ilmu Hukum Deskriptif Empirik,BEE Media Indonesia, Jakarta, 2007

Hilman Syahrial haq. Mediasi komunitas sebagai APS.. Lakeisha. 2019

HR. Ridwan, Hukum Administrasi Negara, Raja Grafindo Persada, Jakarta, 2006

Idris Talib. Bentuk putusan penyelesaian sengketa berdasarkan mediasi. Lex et Societatis, 2013 Jan-Mar; 1(1)

Kamus Besar Bahasa Indonesia.

M. Achadiat Crisdiono. Dinamika etika dan hukum kedokteran dalam tantangan zaman. Jakarta: Penerbit Buku Kedokteran; 2004

Nevey Varida Ariani. "Alternatif penyelesaian sengketa bisnis di luar pengadilan," jurnal Rechtsvinding.2012; 1 (2)

Roeslan Saleh. "Pikiran-pikiran Tentang Pertanggungjawaban Pidana". Ghalia Indonesia. Jakarta. 2002

R.Subekti, Pokok-Pokok Hukum Perdata. Intermasa, Jakarta, 2001

R. Wirjono Prodjodikoro, Asas-Asas Hukum Perjanjian, PT. Bale, Bandung, 1986

Safitri Hariyani, Sengketa Medik (Alternatif PenyelesaianPerselisihan Antara Dokter Dengan Pasien), Diadit Media, Jakarta, 2005

Septa Candra, Pembaharuan Hukum Pidana: Konsep Pertanggungjawaban Pidana dalam Hukum Pidana Nasional yang Akan Datang, Jurnal Cita Hukum Vol 1 No 1,2013, Jakarta

Syahrul Machmud. Penegakan Hukum dan Perlindungan Hukum Bagi Dokter Yang Diduga Melakukan Medikal Malpraktek, Karya Putra Darwati, Bandung, 2012

Veronika Komalawati. Hukum dan etika praktik dokter. Jakarta: Sinar Harapan; 1989 